NBER WORKING PAPER SERIES

\title{
THE DEGREE OF JUDICIAL ENFORCEMENT AND CREDIT MARKETS: EVIDENCE FROM JAPANESE HOUSEHOLD PANEL DATA
}

\author{
Charles Yuji Horioka \\ Shizuka Sekita \\ Working Paper 15631 \\ http://www.nber.org/papers/w15631
NATIONAL BUREAU OF ECONOMIC RESEARCH
1050 Massachusetts Avenue
Cambridge, MA 02138
January 2010

We would like to thank David Blau, Lucia Dunn, Shinya Kajitani, Mari Kan, Wataru Kureishi, Howard P. Marvel, Colin R. McKenzie, Masao Ogaki, Tae Okada, Hiroko Okudaira, Kei Sakata, Keiko Tamada, Midori Wakabayashi, Bruce Weinberg, Keiko Yoshida, and all members of Groupe d'Analyse et de Theorie Economique (GATE), Lyon, France, for their useful advice and suggestions. Moreover, we greatly appreciate detailed comments provided by Alberto Zazzaro, which enabled us to significantly improve our paper. In addition, we would like to thank the Institute for Research on Household Economics for providing micro data from the Japanese Panel Survey of Consumers for the 2003-07 period. This paper was prepared while the second author, Shizuka Sekita, was visiting GATE. Any remaining errors are our own. The views expressed herein are those of the authors and do not necessarily reflect the views of the National Bureau of Economic Research.

NBER working papers are circulated for discussion and comment purposes. They have not been peerreviewed or been subject to the review by the NBER Board of Directors that accompanies official NBER publications.

(C) 2010 by Charles Yuji Horioka and Shizuka Sekita. All rights reserved. Short sections of text, not to exceed two paragraphs, may be quoted without explicit permission provided that full credit, including (c) notice, is given to the source. 
The Degree of Judicial Enforcement and Credit Markets: Evidence from Japanese Household Panel Data

Charles Yuji Horioka and Shizuka Sekita

NBER Working Paper No. 15631

January 2010

JEL No. D12,G21,G33,K12,K41,K42

\begin{abstract}
In this paper, we conduct an empirical analysis of the impact of better judicial enforcement on the probability of being credit rationed, loan size, and the probability of bankruptcy using household-level data from the Japanese Panel Survey of Consumers, conducted by the Institute for Research on Household Economics, in conjunction with judicial data by court district on trial length and the ratio of the number of pending civil trials to the number of incoming civil trials. Contrary to the predictions of the existing theory, we find that better judicial enforcement increases the probability of being credit rationed and decreases loan size. Furthermore, we find that better judicial enforcement increases the probability of bankruptcy, a result that is consistent with lax screening effects.
\end{abstract}

Charles Yuji Horioka

Institute of Social and Economic Research

Osaka University

6-1 Mihogaoka, Ibaraki-shi

Osaka-fu 567-0047 JAPAN

and NBER

horioka@iser.osaka-u.ac.jp

Shizuka Sekita

Institute of Social and Economic Research

Osaka University

6-1, Mihogaoka, Ibaraki, Osaka 567-0047, JAPAN

sekita@iser.osaka-u.ac.jp 
Since the mid-1990s, the impact of legal systems on the economy has been the focus of many theoretical and empirical investigations. As one example of this, many studies, which originate with La Porta, Lopez-De-Silanes, Shleifer, and Vishny (1997), have analyzed the relationship between legal systems and financial markets. In these studies, the following two channels through which the legal system affects financial markets were identified: (1) the degree of judicial enforcement and (2) the content of the law.

In Japan, since laws apply to the nation as a whole, the content of the law is uniform in all judicial districts. However, the degree of judicial enforcement may vary from district to district. Thus, this paper focuses on differences in the degree of judicial enforcement from district to district. The fact that the content of the law is uniform throughout the country in Japan makes it possible to distinguish the impact of the degree of enforcement from that of the content of the law, whereas this is not possible in other countries, where different states have different laws.

The length of trials in Japan has become shorter and shorter over time. For example, the average length of civil trial proceedings in district courts was 17.3 months in 1973, 12.9 months in 1990, and 7.8 months in 2006. In 2003, the "Act on the Expedition of Trials" was promulgated with the objective of concluding trials as quickly as possible and protecting defendants' rights through fair, appropriate, and adequate proceedings. Moreover, Japanese courts have conducted research on how to improve the efficiency of trial proceedings. Several means have been used to achieve this objective--for example, organizing issues more logically and intensively investigating the most appropriate evidence.

Given these changes, the question that arises is how the duration of trials affects economic behavior? Theory predicts that better judicial enforcement (i.e., faster court proceedings) will decrease the probability of being credit rationed, increase loan size, and increase the probability of bankruptcy. In this paper, we conduct an empirical analysis of the impact of better judicial enforcement (i.e., faster court proceedings) on the probability of being credit rationed, loan size, and the probability of bankruptcy using household-level data from the Japanese Panel Survey of Consumers, conducted by the Institute for Research on Household Economics, in conjunction with judicial data by court district on trial length and the ratio of the number of pending civil trials to the number of incoming civil trials.

There are at least three contributions of this paper. First, while many studies conducted in Japan have analyzed the determinants of the probability of being credit rationed and loan size, thus far no study has focused on the impact of the degree of judicial enforcement on credit allocation. This is an important issue, especially in Japan, where the duration of trials has become shorter and is expected to become even shorter in the future. Since the micro data on Japanese households from the "Japanese Panel Survey of Consumers" (hereafter the JPSC) contain detailed information on the respondent's residence, we could combine these data with data on judicial districts and analyze the impact of the degree of judicial enforcement on credit allocation.

Second, in this paper, we controlled for more explanatory variables that capture the local economic situation and local credit market activity than previous studies (for

\footnotetext{
1 In Japanese, Saiban no Jinsokuka ni kansuru Houritsu.

2 In Japanese, Shouhi Seikatsu ni kansuru Paneru Chousa.
} 
example, gross domestic product, the bad loan ratio, market concentration, and the depth of the credit market at the prefectural level). Since the pace at which district courts function is affected by these local factors, it is crucial to control for these factors in order to capture the pure impact of the degree of judicial enforcement.

Finally, our data set allowed us to investigate the impact of the degree of judicial enforcement on the flow (rather than the stock) of debt. The current degree of judicial enforcement can be expected to affect the amount of loans most recently granted by banks, but all previous studies, with the exception of Fabbri (2002), employ the stock of debt to examine the impact of the degree of judicial enforcement on loan size. Most of these studies find the impact of the degree of judicial enforcement to be insignificant, but one possible reason for this is that the stock of debt reflects not only the current choices of lenders and borrowers but also their past choices.

This paper is organized as follows: Section I surveys the results of previous theoretical and empirical studies. In section II, the data used in our estimation are described. In section III, the estimation method and estimation results are presented. Finally, section IV concludes.

To summarize the main findings of this paper, we find that better judicial enforcement increases the probability of being credit rationed and decreases loan size, contrary to the prediction of the existing theory. We provide one possible interpretation of these results at the end of Section III.B. Moreover, we find that better judicial enforcement increases the probability of bankruptcy, a result that is consistent with lax screening effects.

\section{Previous Studies}

In this section, we survey the theoretical and empirical literature on the impact of the degree of judicial enforcement on credit constraints, loan size, and bankruptcy.

First, we survey previous analyses of the impact of the degree of judicial enforcement on credit constraints and loan size. Fabbri and Padula (2004) and Jappelli, Pagano, and Bianco (2005) formalized the economic mechanism through which court performance affects credit allocation. For example, Fabbri and Padula (2004) assumed that a loan contract is securitized with collateral and that, if the borrower fails to repay, the title to the collateral is transferred to the bank. The key assumption is that the judicial system determines when the collateral is transferred to the bank in the case of bankruptcy. If the enforcement procedure is slow, the probability that borrowers are credit constrained might increase because borrowers' incentive to repay loans is reduced. In addition, slower court proceedings might reduce the equilibrium amount of debt because banks would be expected to compensate for the lower liquidation value of the pledged collateral by raising interest rates.

Jappelli, Pagano, and Bianco (2005) employed Italian provincial data for the 1984-95 period as well as data on an indicator of judicial efficiency from the Italian National Institute of Statistics (ISTAT) and found that the stock of pending trials per thousand inhabitants (an indicator of poor judicial enforcement) was significantly associated with (1) more overdraft loans (an indicator of credit constraints) and (2) a lower lending-to-GDP ratio. All of these findings are consistent with their theoretical predictions. Moreover, Fabbri (2002) employed firm-level data from Spain for the year 1998 as well as data on two indicators of the degree of judicial enforcement from the Spanish National Institute of Statistics (INE) and found that both indicators of poor 
enforcement (viz., the length of trials and the number of proceedings that last more than one year divided by the total number of concluded proceedings) have a negative impact on the logarithm of total credit granted during 1998 and on the stock of financial debt. Furthermore, by using firm-level data from Italy for the year 1991 together with the ISTAT data, she found that an indicator of better judicial enforcement (viz., the ratio of completed judicial proceedings to the total number of pending proceedings) has a positive impact on the stock of total debt and that an indicator of poor judicial enforcement (viz., the length of first trials) has a negative impact thereof. ${ }^{3}$

On the other hand, many papers obtain results that do not necessarily support the traditional view of judicial efficiency. For example, Fabbri and Padula (2004) used data from the 1989, 1995, and 1998 waves of the "Survey of Household Income and Wealth (SHIW)" together with the ISTAT data and found that the ratio of the backlog of pending trials to the number of incoming trials (an indicator of poor judicial enforcement) has a significantly positive impact on the probability of being credit constrained, which is consistent with their theory, but that it does not have a significant impact on the amount of debt. Magri (2007) used the 1989, 1995, and 1998 waves of SHIW, the same data set used by Fabbri and Padula (2004), but used a different measure of judicial efficiency: the average time for recovery, which was obtained from a questionnaire sent by the Bank of Italy to Italian banks. She found that recovery time does not have a significant impact on the probability of being rationed or loan size. Alessandrini, Presbitero, and Zazzaro (2008) used the last three waves of Italian firm-level data for the 1995-2003 period together with the ISTAT data and found that the efficiency of courts in recovering bad loans increases the probability of being rationed.

Next, we survey previous analyses of the relationship between the degree of judicial enforcement and bankruptcy. Many economists and legal experts argue that the primary economic function of credit markets is to provide cheap credit. In order to accomplish this goal, they advocate protecting creditor rights strongly. However, credit markets also fulfill other functions, such as the screening of projects. Zazzaro (2005) models the bank's choice of the quality of screening technology and demonstrates that, since improvements in the degree of judicial enforcement might reduce the bank's incentive to adequately screen borrowers, access to credit might be harder (easier) for good-type (bad-type) borrowers. Consequently, better judicial enforcement would worsen credit allocation and increase the bankruptcy rate (see Manove, Padilla, and Pagano (2001) for similar results). Jappelli, Pagano, and Bianco (2005) found that the stock of pending trials per thousand inhabitants (an indicator of poor judicial enforcement) is significantly associated with a lower ratio of nonperforming loans to total loans, which is consistent with the theoretical result of Zazzaro (2005). Grant and Padula (2006) used Italian household data from Findomestic Banca for the 1995-99 period together with the ISTAT data and found that the length of trials does not have a significant impact on the probability of repayment. This result is not surprising because the data they used specializes in unsecured credit, and the main channel through which the degree of judicial enforcement affects repayment behavior is collateral.

\footnotetext{
${ }^{3}$ The length of second and third (appeal) trials does not have a significant impact on the stock of total debt.
} 
The present paper first tests whether better judicial enforcement decreases the probability of being rationed and increases loan size (Sections III.A and B). Surprisingly, the estimation results of this paper are opposite in sign to the theoretical predictions of the traditional view, and we provide one possible interpretation at the end of Section III.B. We then examine the impact of the degree of judicial enforcement on the probability of bankruptcy in Section III.C. Our findings are consistent with the lax screening effect of Zazzaro (2005), whereby better judicial enforcement increases the probability of bankruptcy by worsening the quality of credit allocation.

\section{Data}

In this section, we discuss the data sources used in our analysis and present descriptive statistics of our variables pertaining to the degree of judicial enforcement.

\section{A. Household Data}

The Japanese Panel Survey of Consumers (JPSC) is a panel survey of young Japanese women that has been conducted annually since 1993 by the Institute for Research on Household Economics. ${ }^{4}$ This paper employs data from the 2003-07 waves of this survey because these waves asked respondents whether or not they (or their spouses) were credit constrained during the past year. ${ }^{5}$ While the respondents are all women, the survey questions pertain to the respondents as well as their family members, including spouses, children, and parents. The number of observations in 2003, 2004, 2005,2006 , and 2007 was 2136, 1977, 1863, 1770, and 1694, respectively; thus, our study used an unbalanced panel. After excluding observations that had missing values for the variables included in our analysis, the number of observations that remained was between 1200 and 1500 in each year. In sections III.A and III.B, we use only those observations in which the household applied for a loan during the past year in order to identify households that were rationed by banks. Households that applied for a loan during the past year comprise just over $10 \%$ of the total $(=710 / 6862)$. In particular, such households numbered 166, 157, 125, 150, and 112 in 2003, 2004, 2005, 2006, and 2007, respectively.

There are three advantages to using data from the JPSC. The biggest advantage of using the JPSC data is that this data set includes detailed information regarding the respondent's place of residence. Thus, we were able to match observations from the JPSC data with the judicial data of the relevant district court (see section II.B for details). The second advantage of the JPSC is that it collects data on the size of loans granted by financial institutions during the survey year. In many previous studies regarding the degree of judicial enforcement, data on the flow of debt are not available

\footnotetext{
${ }^{4}$ In Japanese, Kakei Keizai Kenkyuusho.

${ }^{5}$ While questions pertaining to credit constraints were included in the 1993 wave as well as in all waves after 1998, until 2002, the survey only asked whether respondents (or their spouses) had ever been credit constrained, and thus it is impossible to distinguish exactly when they were credit constrained. For this reason, in this study, we do not use the 1993-2002 waves. In addition, unfortunately, in the 2003 wave, respondents aged between 24 and 29 were asked about whether they had ever been credit constrained. Therefore, we had no choice but to assume that respondents aged between 24 and 29 in 2003 who had ever been credit constrained were credit constrained during the past year.
} 
and hence data on the stock of debt are used. However, the stock of debt reflects the past as well as current choices of lenders and borrowers, whereas the current degree of judicial enforcement would be expected to affect the credit amount most recently granted by banks. Thus, in our study, we use data on the flow of debt as our measure of loan size. The third advantage of the JPSC is that, although it does not collect data on whether or not the respondent applied for a loan, it is possible to identify loan applicants by using questions on the flow of debt in conjunction with those on credit constraints (see section III.A for details).

\section{B. Data on Judicial Districts}

There are several types of courts in Japan: the Supreme Court, high courts, district courts, summary courts, and family courts. When a borrower fails to repay his or her loan and the lender wishes to seize the borrower's property and sell it through a court order, the lender must appeal to a district court. In principle, when a plaintiff (lender) wishes to appeal to a court, the competent court is that of the district where the defendant (borrower) lives or where the collateral is located. We used data on all 50 district courts, taken from the Public Relations Division of the Supreme Court and the Annual Report of Judicial Statistics, published by the General Secretariat of the Supreme Court of Japan. All prefectures other than Hokkaido have one district, whereas Hokkaido has four. This means that it is necessary to obtain information regarding the city in which Hokkaido respondents reside. Fortunately, our data set collects information regarding the city, town, or village in which the respondent lives. Thus, we were able to match observations from the JPSC data with judicial data on the relevant district court. ${ }^{6}$

In our study, we employed two indicators of the degree of judicial enforcement. The first indicator is the length of trials in each district court during the 2003-07 period. ${ }^{7} \quad$ Data on the length of trials include all first civil trials in district courts. They represent the average amount of time between the date of the initial recording of a trial and that of the court verdict in each year. ${ }^{8}$ In the regression analysis, we use three dummy variables ( $1^{\text {st }}$ Enforcement Quartile1, $2^{\text {nd }}$ Enforcement Quartile1, and $3^{\text {rd }}$

\footnotetext{
${ }^{6}$ In fact, the court performance of high courts and summary courts may also affect credit allocation. This is because high courts have jurisdiction over appeals lodged against judgments of district courts. Another reason is that in order to seize the borrower's property through a court order, lenders need to obtain official documents that show the existence of the right to claim loan repayment from summary courts. Thus, in section III, we also use judicial data on high courts and summary courts to conduct robustness checks.

${ }^{7}$ We would like to thank the Public Relations Division of the Supreme Court for providing us with data on the length of trials in each judicial district. Since the data are for the 1989-2006 period, we constructed the length of trials for the year 2007 by using linear, log, exponential, quadratic, and power approximations and by choosing the approximation with the highest R-squared for each judicial district. The equations calculated by Excel are as follows: $\mathrm{Y}=\mathrm{a}+\mathrm{b} * \mathrm{X}, \mathrm{Y}=\mathrm{a}+\mathrm{b}$ * $\log (\mathrm{X}), \mathrm{Y}=\mathrm{a} * \exp (\mathrm{b} * \mathrm{X}), \mathrm{Y}=\mathrm{a}+\mathrm{b} * \mathrm{X}+\mathrm{c} * \mathrm{X}^{2}$, and $\mathrm{Y}=\mathrm{a} * \mathrm{X}^{\mathrm{b}}$, respectively. $\mathrm{Y}$ is the length of trials, and $\mathrm{X}$ is the year.

${ }^{8}$ In order to avoid measurement error, previous studies used indicators of the degree of judicial enforcement that excluded cases with no relation to loan contracts. Unfortunately, we were unable to obtain data on the length of trials broken down by the type of case. Thus, the average length of trials for all civil cases is used in this study. However, for the second indicator of judicial enforcement, we excluded all work- and family-related cases.
} 
Enforcement Quartile1), which represent quartiles of the distribution of the length of trials, with the highest quartile ( 8.8 months or more) being the excluded category. More specifically, $1^{\text {st }}$ Enforcement Quartilel is a dummy variable that equals one if the length of trials is less than 7.4 months and zero otherwise, $2^{\text {nd }}$ Enforcement Quartile1 is a dummy variable for trials between 7.4 and 8.1 months, and $3^{\text {rd }}$ Enforcement Quartile1 is a dummy variable for trials between 8.1 and 8.8 months. Thus, these dummy variables indicate better judicial enforcement as compared to the excluded category.

The second indicator of the degree of judicial enforcement that we use is the ratio of the number of pending civil trials to the number of incoming civil trials in each district during the 2003-07 period. The data include all civil trials except for workand family-related cases. The ratio of the number of pending civil trials to the number of incoming civil trials reflects the duration of future trials, while the length of trials (the first indicator) reflects the duration of current and past trials. While many previous studies have used the number of pending trials as an indicator of poor judicial enforcement, they have used different normalization measures such as population, the number of judges, and the number of court personnel. In our analysis, we normalized the number of pending trials by the number of incoming trials, as done by Fabbri and Padula (2004), but the estimation results do not change even if we use different normalization measures such as population and the number of judges. As in the case of the first indicator of the degree of judicial enforcement, we used three dummy variables for the second indicator-- namely, $1^{\text {st }}$ Enforcement Quartile2, $2^{\text {nd }}$ Enforcement Quartile2, and $3^{\text {rd }}$ Enforcement Quartile2, with the highest quartile (45.5 or higher) being the excluded category. $1^{\text {st }}$ Enforcement Quartile2 is a dummy variable that equals one if the pending rate is less than $39.9 ; 2^{\text {nd }}$ Enforcement Quartile2 is a dummy variable for pending rates between 39.9 and 43.0, and $3^{\text {rd }}$ Enforcement Quartile2 is a dummy variable for pending rates between 43.0 and 45.5. Thus, these dummy variables indicate better judicial enforcement than the excluded category.

In the first section, we stated that the duration of court proceedings in Japan has declined over time. The question that arises is how the length of trials in Japan compares to that in other countries. According to "The Second Report on the Acceleration of Trials," " the length of first civil trials in 2004 was 8.3 months in Japan, 22.4 months in England, 9.6 months in France, and 8.5 months in the U.S. The only country with shorter trials than Japan (7.2 months) was Germany. In addition, Djankov, La Porta, Lopez-de-Silanes, Shleifer (2003) compared the duration of the process for collecting on a check returned for non-repayment in 109 countries, and according to their study, Japan ranked seventh from the bottom, with the process lasting 60 months. ${ }^{10}$ Thus, it can be stated that the duration of trials in Japan is short even by international standards.

(Insert Figures 1 and 2 here)

\footnotetext{
${ }^{9}$ In Japanese, Saiban no Jinsokuka ni kakaru Kenshou ni kansuru Houkokusho (Dai Ni-kai). http://www.courts.go.jp/about/siryo/jinsoku/hokoku/02/index.html

${ }_{10}$ Djankov, La Porta, Lopez-de-Silanes, Shleifer (2003) also calculate the average duration of the procedure for evicting a residential tenant for nonpayment of rent and find that the average duration of such a procedure in Japan is 363 months and that Japan ranks 87 among the 109 countries in their sample.
} 
We now present data on the two indicators of the degree of judicial enforcement across different districts in Japan. Figures 1 and 2 show data on the length of trails and the ratio of the number of pending trials to the number of incoming trials, respectively, in each district court. Figure 1 shows data on the length of trials in all 50 district courts in Japan, with the upper half of this figure showing data for 2000 and the lower half showing data for 2006, and as is evident from this figure, the length of trials was much shorter in 2006 than it was in 2000 in all districts, meaning that the degree of judicial enforcement improved throughout the country. The median length of trials was 9.0 months in 2000 but only 7.7 months in 2006. As can be seen from the gray bars, which indicate districts in which trials are longer than the median, poor judicial enforcement persists in some areas. For instance, if we were to divide Japan into eight regions (namely, Hokkaido, Tohoku, Kanto, Chubu, Kinki, Chugoku, Shikoku, and Kyushu), we would conclude that the degree of judicial enforcement is the worst in Chubu, Kanto, and Shikoku. By contrast, trials in Hokkaido were particularly short in both 2000 and 2006.

Figure 2 shows data on the ratio of the number of pending trials to the number of incoming trials for all 50 districts, and as can be seen from this figure, this variable shows similar patterns to those for the length of trials shown in Figure 1. While the ratio of pending trials to incoming trials declined in 2006, it is still high in Chubu and Kanto. In addition, the ratio of pending trials to incoming trials in Hokkaido is smaller than the median, indicating that the degree of judicial enforcement is higher in Hokkaido than it is in other areas.

\section{Results}

In this section, we present the results of our empirical analysis of the impact of better judicial enforcement on the probability of being rationed (Section III.A), on loan size (Section III.B), and on the probability of bankruptcy (section III.B).

\section{A. The Probability of Being Credit Constrained and the Degree of Judicial Enforcement}

According to the theoretical model of Fabbri and Padula (2004), households are less likely to be credit constrained when loan contracts are enforced more strongly because households' incentive to repay increases. In this section, we test whether better judicial enforcement decreases the probability of being rationed using both a pooling logit model and a random effects logit model.

$$
\begin{array}{r}
\mathrm{R}_{\mathrm{it}}{ }^{*}=\boldsymbol{X}_{\mathrm{it}} \boldsymbol{a}+\boldsymbol{E}_{\mathrm{it}} \boldsymbol{b}+v_{\mathrm{i}}+\boldsymbol{\varepsilon}_{\mathrm{it}}, \\
\mathrm{R}_{\mathrm{it}}=1 \text { if } \mathrm{R}_{\mathrm{it}}{ }^{*}>0 \\
\mathrm{R}_{\mathrm{it}}=0 \text { if } \mathrm{R}_{\mathrm{it}} \leq 0
\end{array}
$$

$\mathrm{R}_{\mathrm{it}}{ }^{*}$ is an unobserved variable that is related to an observed variable on credit constraints $\mathrm{R}_{\mathrm{it}}$, and $\boldsymbol{X}$ are economic and demographic household characteristics that affect loan supply and demand, and $\boldsymbol{E}$ are three dummy variables ( $1^{\text {st }}$ Enforcement Quartile, $2^{\text {nd }}$ Enforcement Quartile, and $3^{\text {rd }}$ Enforcement Quartile) that indicate better judicial enforcement compared to the excluded category (see section II B for details). Thus, the expected signs of the marginal effects of $\boldsymbol{E}$ are negative. 
In order to identify credit-constrained households, we first need to identify loan applicants because households that did not apply for a loan cannot, by definition, be rationed by banks. While the JPSC does not ask any questions about whether or not households applied for a loan, it does collect data on the amount of loans granted by financial institutions during the past year. We defined households that were granted credit during the past year as well as those that were not granted credit and whose loan applications were rejected as loan applicants.

To determine whether households are credit constrained, we employed the responses to the following questions in the survey: "Was your (or your spouse's) loan application turned down during the past year?" and "Was you (or your spouse's) loan amount reduced when you applied for a loan during the past year?" 11 Respondents who replied "yes" to one or both of the above questions were regarded as being credit constrained.

With regard to the household characteristics that influence credit rationing, we employed (1) the age and the square of the age of respondents ( $A G E, A G E D)$; (2) the logarithm of the monthly disposable income of respondents (LINC), ${ }^{12}$ (3) a dummy variable that equals one if respondents are self-employed (SELF-EMPLOYED); (4) a dummy variable that equals one if respondents are unemployed (UNEMPLOYED); (5) the ratio of the monthly amount of loan repayments to monthly income (REPAY); (6) a dummy variable that equals one if respondents work in the same company in which they worked a year earlier (TENURE); (7) a dummy variable that equals one if the respondent graduated from college (COLLEGE); (8) the logarithm of the sum of the value of financial assets (bank and postal deposits and investment securities) and the value of real assets (land and housing) (LWEALTH); (9) the logarithm of loans outstanding (LLOAN); (10) a dummy variable that equals one if the respondent owns her own home (HOME); (11) a dummy variable that equals one if the respondent is married (MARRIED); (12) the number of children (CHILD); (13) a dummy variable that equals one if respondents live in metropolitan areas (METRO); (14) a dummy variable for medium city (MEDIUM CITY); (15) seven area dummies (AREA1-7); and (16) dummies for each year (YEAR2004-07). ${ }^{13}$ In addition, in order to take account of the regional economic situation and credit market activity, we included the per capita gross prefectural product in each prefecture (PREFECTURAL GDP), the ratio of

\footnotetext{
${ }^{11}$ Many previous studies of borrowing constraints such as Cox and Jappelli (1993) and Duca and Rosenthal (1993) include households that were discouraged from applying for a loan. While the survey we used also collects the information needed to identify discouraged borrowers, we did not include them in rationed households because discouraged borrowers fall in the subsample of those who did not apply for a loan. However, we also tried classifying discouraged households as rationed households as a robustness check at the end of this section.

${ }^{12}$ The reason why we did not use annual disposable income is that the survey asks respondents about annual income earned in the previous calendar year and taxes paid in the previous calendar year. Thus, if we had used annual disposable income, we would not have been able to use data for 2007. In order to avoid a further reduction in the number of observations, we employed monthly disposable income, which is available for the current calendar year.

13 Our data set includes data on married as well as single respondents. With respect to $A G E$, AGED, LINC, SELF-EMPLOYED, UNEMPLOYED, REPAY, TENURE, and COLLEGE, we use data on the respondent's husband if the respondent is married and data on the respondent herself only if she is single because husbands are more likely to be the household head or the primary income earner.
} 
nonperforming loans to total lending in regional banks by prefecture (BAD LOANS), the Herfindahl-Hirschman Index (the sum of the squared individual shares of lending in regional banks by prefectures) (HERFINDAHL), and the ratio of total lending in each prefecture to prefectural GDP $(D E P T H) .{ }^{14}$

In the estimation, we focus only on households that applied for a loan during the past year. This is because we cannot determine whether or not households were rationed by banks if they did not apply for a loan. However, there is a possibility that using this subsample will result in sample selection bias because there might be a correlation between the unobservable factors that decide the probability of applying for a loan and those that decide the probability of being credit constrained. Although we used a maximum-likelihood probit model with sample selection, ${ }^{15}$ the correlation between error terms of the two equations was not statistically different from zero for any specifications. ${ }^{16}$ Thus, we used only the sample of loan applicants in our estimation.

\section{(Insert Table 1 here)}

Table 1 presents characteristics of loan applicants broken down by whether or not they are credit-rationed. ${ }^{17}$ Rationed households comprise $21 \%$ of the total (149/710). A comparison of rationed households with non-rationed households shows that rationed households have lower income, wealth, homeownership, debt, tenure, educational attainment, and per capita gross prefectural product than non-rationed households. In addition, rationed households are more likely to be self-employed or unemployed and less likely to live in metropolitan areas. Moreover, rationed households have more children and higher loan repayments than non-rationed households. With respect to the judicial variables of interest, the means of $2^{\text {nd }}$ Enforcement Quartilel and $1^{\text {st }}$ Enforcement Quartile2 are slightly higher in the case of rationed households than they are in the case of non-rationed households, which implies that better judicial enforcement increases the probability of being rationed. Looking at the means of $2^{\text {nd }}$

\footnotetext{
${ }^{14}$ Magri (2007) controlled for the portion of the loan that is recovered in the event of a borrower's bankruptcy, but unfortunately, we were unable to control for this variable because of the lack of data. ${ }^{15}$ We used the heckprob command in STATA 9.

${ }^{16}$ Magri (2007) also found that the hypothesis that the errors in the two equations are uncorrelated cannot be rejected.

${ }^{17}$ The total number of observations, including loan applicants and non-applicants was 6862 , and the number of households whose loan applications were rejected and/or whose loan size was reduced was 149 . Thus, on average, only $2 \%(149 / 6862)$ of households were credit constrained during the 2003 to 2007 period. However, if we include discouraged borrowers in rationed households in addition to rejected and reduced households, the share of rationed households increases to $4 \%$ (292/6862). Kohara and Horioka (2006), who used different waves of the same survey that we used, found that $7.61 \%, 9.29 \%$, and $15.40 \%$ of households were rejected, reduced, and/or discouraged in 1993, 1998, and 2003, respectively. In our study, the proportion of rationed households is far less, but this difference is due mainly to the difference in the definition of credit constraints. While Kohara and Horioka (2006) include households that were credit constrained in the past in credit-constrained households, we include only households that were credit-constrained during the past year in credit-constrained households. If we use the same definition as that of Kohara and Horioka (2006), the proportion of credit-constrained households increases to $10 \%$ $(128 / 1226)$ in 2007 , which is relatively similar to the proportion of rationed households calculated by Kohara and Horioka (2006).
} 
and $3^{\text {rd }}$ Enforcement Quartile2, however, they are higher in the case of non-rationed households than they are in the case of rationed households. Thus, the impact of better judicial enforcement is not clear from the descriptive statistics.

\section{(Insert Table 2 here)}

We turn now to the estimation results. The results for the pooling logit model are shown in columns (1) and (2) of Table 2, whereas the results for the random effects logit model are shown in columns (3) and (4) of the same table. ${ }^{18}$ Let us first consider the impact of household characteristics on the probability of being rationed. From the viewpoint of supply-side adverse selection, the debt ceiling should be lower for younger borrowers and therefore an increase in $A G E$ should relax credit constraints. In most cases, $A G E$ has a significantly negative impact on the probability of being rationed, as expected. For example, the marginal effects of $A G E$ and $A G E D$ in (3) indicate that the probability of being rationed decreases until borrowers are about 41 years old $(0.0826$ / $(2 * 0.0010))$ and then approaches zero. With respect to the impact of income, LINC does not have a significant impact in any case. The insignificance of the marginal effect of LINC is contrary to expectation because an increase in income would be expected to relax credit constraints and is also contrary to the empirical evidence for the U.S. but is consistent with the findings of Kohara and Horioka (2006), who found that, in Japan, income is not an important factor in determining the probability of being rationed. With respect to the impact of $L W E A L T H$, we found that it has a significantly negative impact in most cases, which is as expected because if households' assets are higher, we would expect the demand for credit to decrease and the debt ceiling to increase. In addition, the marginal effects of $H O M E$ are insignificant in all cases, which is contrary to our expectation because we expected homeownership to be a proxy for collateral and for previous good credit records. $L L O A N$ was found to have a significantly negative impact on the probability of being rationed. We expected that the higher are loans outstanding, the greater would be the probability of being rationed, but the negative impact we find might imply that large amounts of outstanding loans function as an indicator of good credit records in the past. While SELF-EMPLOYED was found to have a significantly positive impact on the probability of being rationed in model (2), as expected, the marginal effects of UNEMPLOYED were found to be insignificant in all cases. REPAY had a significantly positive impact on the probability of being rationed in all cases, which is as expected because the higher is the value of REPAY, the lower will be the ability to repay. The results for TENURE imply that if tenure is longer, the probability of being rationed decreases, as expected. Moreover, while Kohara and Horioka (2006) found that college graduates are significantly less likely to be borrowing constrained, in our results, the marginal effect of COLLEGE was insignificant, as found by Jappelli (1990). MARRIED has a significant positive impact on the probability of being rationed. This result is contrary to our expectation because, in general, we would expect married couples to be less likely to be rationed because their desired borrowing is lower than that of single people due to economies of scale

\footnotetext{
${ }^{18}$ We performed a likelihood-ratio test and found that the null hypothesis - that the proportion of the total variance contributed by the panel-level variance component equals zero-was rejected. This indicates that the panel-level variance component is important and thus that a random effects logit model is preferable to a pooling logit model.
} 
and because their debt ceiling is higher than that of single people due to factors such as lower mobility. With respect to CHILD, we found that it has a significantly positive impact, which is as expected because if households have more children, we would expect their desired borrowing to increase and their credit constraints to become tighter. With respect to the remaining explanatory variables, it appears that city size (METRO and $M E D I U M$ CITY) does not have a significant impact on the probability of being rationed. Additionally, prefectural variables such as BAD LOANS and HERFINDAHL do not have a significant impact on the probability of being rationed, while PREFECTURAL GDP (DEPTH) has a significant negative (positive) impact on the probability of being rationed in some cases.

With respect to the judicial variables of interest, none of the three dummy variables for Enforcement Quartile2 had a significant impact on the probability of being rationed. On the other hand, $2^{\text {nd }}$ Enforcement Quartilel had a significantly positive impact on the probability of being rationed in model (1) of Table 2 even though all of the marginal effects of Enforcement Quartilel are insignificant in model (3) of the same table. The results for the pooling logit model suggest that better judicial enforcement increases the probability of being rationed, contrary to theoretical prediction. Considering the magnitude of the marginal effects of $2^{\text {nd }}$ Enforcement Quartilel in model (1) of Table 2, the probability of being rationed is 11 percentage points higher in judicial districts with second-best judicial enforcement than in judicial districts with the worst judicial enforcement. As stated before, the percentage of rationed households was $21 \%$, which means that moving from the worst judicial enforcement district to the second-best judicial enforcement district increases the probability of being rationed by $52 \%((11 / 21) * 100)$.

As robustness checks, we first tried using dummy variables pertaining to the length of trials and to pending rates in high courts rather than in district courts. High courts are located in eight major cities in Japan, and some high courts have branch courts (there are six branch courts in all of Japan). Thus, the judicial data on high courts consist of only 14 categories in each year, which means that variation in the judicial data on high courts across individuals is considerably smaller than that in the judicial data on district courts. As expected, dummy variables pertaining to the length of trials and pending rates in high courts either did not have a significant impact on the probability of being rationed or were dropped during the estimation due to colinearity. Second, we tried using dummy variables pertaining to pending rates in summary courts. ${ }^{19}$ The judicial data on summary courts consist of 50 categories in each year, which is the same number as in the case of district courts. The dummy variables pertaining to pending rates in summary courts did not have a significant impact on credit allocation. This result is consistent with the results presented in Table 2, which are based on dummy variables pertaining to pending rates in district courts, and suggests that the future duration of trials might be irrelevant in determining the probability of being rationed. ${ }^{20}$

Lastly, we tried including discouraged borrowers, who were previously excluded because they did not apply for a loan, in rationed households. We found that this

\footnotetext{
${ }^{19}$ For summary courts, no data are available on the length of trials.

${ }^{20}$ We also tried using the length of trials and that of the ratio of the number of pending trials to the number of incoming trials instead of dummy variables thereon and found that the marginal effects of the two are insignificant with respect to the probability of being rationed.
} 
caused the impact of judicial enforcement on the probability of being rationed to become more significant. More specifically, in the pooling logit model, all the dummy variables for Enforcement Quartilel had a significantly positive impact on the probability of being rationed. Moreover, in the random effects logit model, $2^{\text {nd }}$ and $3^{\text {rd }}$ Enforcement Quartile1 had a significantly positive impact on the probability of being rationed. These results provide further support for the view that better judicial enforcement increases the probability of being rationed, as shown in model (1) of Table 2 , and are again contrary to theoretical prediction.

\section{B. Loan Size and the Degree of Judicial Enforcement}

In theory, if the degree of judicial enforcement is weak, banks would be expected to try to compensate for the lower liquidation value of the pledged collateral by raising interest rates, and this will reduce loan size in equilibrium. In this section, we test whether better judicial enforcement increases loan size. According to the JPSC data, $12 \%$ of loan applicants were not granted any credit during the past year. In order to take account of the widespread presence of zeros regarding loan size, we conducted both pooling Tobit ${ }^{21}$ and random effects Tobit estimations. ${ }^{22}$

$$
\mathrm{L}_{\mathrm{it}}=\boldsymbol{X}_{\mathrm{it}} \boldsymbol{a}+\boldsymbol{E}_{\mathrm{it}} \boldsymbol{b}+v_{\mathrm{i}}+\varepsilon_{\mathrm{it}}
$$

The dependent variable we use in this analysis is the logarithm of loan size granted by banks during the past year, while the explanatory variables are the same as those described in Section III.A. Thus, the expected signs of the marginal effects of better judicial enforcement $\boldsymbol{E}$ are positive.

(Insert Table 3 here)

The estimation results are shown in Table 3. Looking first at the impact of household characteristics, LWEALTH has a significantly positive impact in every case, which is as expected because if households have more wealth, they can pledge more collateral to lenders. On the other hand, HOME has a significantly negative impact on loan size, which might be because owning a home lowers the demand for new (housing) loans. $L L O A N$ has a significantly positive impact on loan size, which might be the result of a simultaneity problem arising from the fact that $L L O A N$ includes not only loans granted more than one year earlier but also loans granted during the past year. The inference is supported by the fact that if we exclude loans granted during the past year from $L L O A N$, the marginal effects of $L L O A N$ become insignificant in most cases. Furthermore, we found that TENURE has a significantly positive impact on loan size, which is consistent with our expectations. MARRIED has a significantly negative impact on loan size, and this might be because married couples have a lower demand for loans as a result of economies of scale in the consumption of durables. In addition, CHILD has a significantly negative impact on loan size, which might be because the

\footnotetext{
${ }^{21}$ We utilized an interval regression with left-censoring of observations and robust standard errors adjusted for clusters in households to estimate our Tobit model.

${ }_{22}^{2}$ The null hypothesis (that the panel-level variance component equals zero) was rejected. This result indicates that the panel-level variance component is important and thus that a random effects Tobit model is preferable to a pooling Tobit model.
} 
debt ceiling allowed by banks decreases when households have more children.

With respect to the judicial variables of interest, the marginal effects of all dummies pertaining to Enforcement Quartile2 were insignificant. On the other hand, the marginal effects of all dummy variables pertaining to Enforcement Quartile 1 were significantly negative. These results are again contrary to our expectation that better judicial enforcement increases the credit granted by lenders. Moreover, the magnitude of the impact of a change in the degree of judicial enforcement is considerable. The estimation results derived from the random effects Tobit model suggest that moving from a judicial district with the worst judicial enforcement to judicial districts with the best, second best, and third best judicial enforcement reduces loan size by $78 \%$ $((\exp (-1.5215)-1) * 100), 76 \%((\exp (-1.4181)-1) * 100)$, and $56 \%((\exp (-0.8137)-$ $1) * 100)$, respectively.

In order to check the robustness of our results, we first tried using the length of trials and the ratio of the number of pending trials to the number of incoming trials instead of using dummy variables thereon. We found that the marginal effect of the length of trials was significantly positive with respect to loan size both in the pooling Tobit and random effects Tobit models, which is consistent with the results shown in Table 3. Second, we tried using dummy variables pertaining to the pending rates in summary courts ${ }^{23}$ and found that the dummy variables pertaining to pending rates in summary courts did not have significant impact on loan size, which is also consistent with the results shown in Table 3.

Based on the estimation results presented in sections III.A and III.B, we can conclude that better judicial enforcement increases the probability of being rationed and decreases loan size. These results are opposite in sign to the theoretical results of Fabbri and Padula (2004) and Jappelli, Pagano, and Bianco (2005). We provide one possible theoretical explanation of our findings below: ${ }^{24}$

Credit markets operate under substantial asymmetries of information. For example, borrowers may be either creditworthy and honest, or dishonest. The former type of borrower repays its debts as long as it has the ability to do so, while the latter type of borrower never repays its debts. Although the lender understands that borrowers are heterogeneous, she is unable to distinguish one from the other. Assume that there are two ways to screen borrowers. One is a more costly but more effective way, which produces a more informative signal about the type of borrower. The other is a less costly but less effective way. In particular, think of delayed information revelation as a less effective way of screening. There may not be sufficient information about some borrowers when they apply for a loan, but with some low-intensive monitoring, more information might become available later. Examples of what this type of screening might involve are: (a) cutting the amount of the initial loan, and conditional on adverse information not being revealed later or on good information being revealed later, increasing the loan amount after some time and (b) rejecting an initial application, presenting the borrower with a harsher budget constraint for a while so that the borrower disciplines herself, and then extending the loan. There is one crucial assumption that is needed here-namely that if the more costly but more effective screening method is used at the optimal intensity, then the benefits from

\footnotetext{
${ }^{23}$ For summary courts, no data are available on the length of trials.

24 This interpretation was suggested by an anonymous referee of this journal. We greatly appreciate his/her enormous help and contribution.
} 
information generated by the less costly screening method do not outweigh the costs. If this assumption is satisfied, the intensity of the costly screening method will be high and the costless screening method will become redundant when the degree of judicial enforcement is weak. However, when the degree of judicial enforcement is strong, the intensity of the costly screening method will be reduced, and the benefits from the less costly screening method will outweigh the costs. As argued above, by its very nature, this screening method might involve cutting the initial loan size and denying approval to elicit more information.

\section{The Probability of Bankruptcy and the Degree of Judicial Enforcement}

If the degree of judicial enforcement is strong, banks may not screen borrowers adequately and erroneously evaluate bad (good) borrowers as good (bad) ones, resulting in an increase in the probability of bankruptcy. In this section, we test whether or not better judicial enforcement increases the probability of bankruptcy. Although we were inclined to take advantage of the panel nature of the data, panel logit estimation did not work well because only a small number of households went bankrupt. Therefore, we chose to conduct a pooling probit estimation.

$$
\begin{array}{r}
\mathrm{B}_{\mathrm{i}}{ }^{*}=\boldsymbol{X}_{\mathrm{i}} \boldsymbol{a}+\boldsymbol{E}_{\mathrm{i}} \boldsymbol{b}+\boldsymbol{A}_{\mathrm{i}} \boldsymbol{c}+v_{\mathrm{i}}, \\
\mathrm{B}_{\mathrm{i}}=1 \text { if } \mathrm{B}_{\mathrm{i}}{ }^{*}>0 \\
\mathrm{~B}_{\mathrm{i}}=0 \text { if } \mathrm{B}_{\mathrm{i}}{ }^{2} \leq 0
\end{array}
$$

$\mathrm{B}_{\mathrm{it}}{ }^{*}$ is an unobserved variable that is related to observed data on bankruptcy B. To construct the dependent variable, we used the following two questions: "Did you experience personal bankruptcy or the bankruptcy of your own company during the past year?" and "Did you have difficulty making loan repayments during the past year?" The former question is the most appropriate one for testing our hypothesis, and thus the latter question appears to be redundant. However, since households that went bankrupt comprise only $0.2 \%$ of the total (14/6222), commonly used statistical procedures such as probit might not be estimated. Therefore, we also took account of information regarding difficulties with loan repayments because households experiencing such difficulties presumably have a higher probability of future bankruptcy. More specifically, we defined a dummy variable that equals one if households answered "yes" to at least one of these two questions and zero otherwise and used it as our dependent variable.

For explanatory variables that affect bankruptcy, we used the same explanatory variables $\boldsymbol{X}$ as in sections III.A and III.B, with the exception of UNEMPLOYED. Moreover, we used three dummy variables $\boldsymbol{A}$ that indicate adverse events. ${ }^{25}$ The three dummy variables we used are DIVORCE (whether or not the respondent was divorced during the past year), LOST JOB (whether or not the respondent or her family members lost their jobs during the past year), ${ }^{26}$ and SICK (whether or not the respondent or her family members were sick during the past year). $\boldsymbol{E}$ represents three dummy variables ( $1^{\text {st }}$ Enforcement Quartile, $2^{\text {nd }}$ Enforcement Quartile, and $3^{\text {rd }}$ Enforcement Quartile), as

\footnotetext{
${ }^{25}$ See, for example, Fay, Hurst, and White (2002) for an empirical study that investigates the impact of adverse events on personal bankruptcy.

26 We dropped UNEMPLOYED because we wanted to include LOST JOB and because UNEMPLOYED and LOST JOB are highly correlated.
} 
in sections III.A and III.B. Thus, the expected signs of the marginal effects of $\boldsymbol{E}$ are positive.

\section{(Insert Table 4 here)}

The estimation results are shown in Table 4. Looking first at the estimation results pertaining to household characteristics, although the level of income does not have a significant impact on the probability of bankruptcy, all adverse events (DIVORCE, LOST JOB, and SICK) that reduce the ability to repay loans have a significantly positive impact on the probability of bankruptcy. Moreover, the magnitudes of these effects are also pronounced: DIVORCE, LOST JOB, and SICK increase the probability of bankruptcy by $1.97,1.01$, and 0.11 percentage points, respectively. Since the share of bankrupt households is $0.56 \%$, divorce, losing a job, and becoming sick increase the probability of bankruptcy by $352 \%, 180 \%$, and $20 \%$, respectively. Moreover, although we found that LWEALTH, SELF-EMPLOYED, REPAY, TENURE, MARRIED, BAD LOANS, and HERFINDAHL have a significant impact on the probability of bankruptcy although the magnitudes of their marginal effects are not very large.

Let us look next at the role played by the degree of judicial enforcement. As expected, the $1^{\text {st }}$ and $2^{\text {nd }}$ Enforcement Quartile1 and $1^{\text {st }}$ Enforcement Quartile2 all have a positive impact on the probability of bankruptcy. These results imply that better judicial enforcement increases the probability of bankruptcy, as shown in Zazzaro (2005). To appreciate the magnitude of this distortion, we computed how the probability of bankruptcy changes if the average household moves from a judicial district with the worst judicial enforcement to a district with better judicial enforcement. Using the results for Enforcement Quartilel as an example, moving from a judicial district with the worst judicial enforcement to a district with the best and second-best judicial enforcement increases the probability of bankruptcy by 0.16 and 0.21 percentage points, respectively. Since the proportion of bankrupt households is $0.56 \%$, the probability of bankruptcy is $29 \%$ and $38 \%$ higher in judicial districts with the best and second-best judicial enforcement than it is in judicial districts with the worst judicial enforcement.

\section{Conclusion}

In this paper, we conducted an empirical analysis of the impact of better judicial enforcement (i.e., faster court proceedings) on the probability of being credit rationed, loan size, and the probability of bankruptcy using household-level data from the Japanese Panel Survey of Consumers, conducted by the Institute for Research on Household Economics, in conjunction with judicial data by court district on trial length and the ratio of the number of pending civil trials to the number of incoming civil trials.

The existing theory predicts that, if the degree of judicial enforcement is strong, the household's incentive to repay its loans will increase and banks will be less likely to ration credit. In addition, since better judicial enforcement makes the liquidation value of the pledged collateral higher, banks should reduce interest rates and loan size should increase in equilibrium when the degree of judicial enforcement is strong. However, contrary to this traditional view, we found that better judicial enforcement increases the probability of being credit rationed and decreases loan size. The following is a 
possible interpretation of this result. Since the intensity of costly screening is reduced if the degree of judicial enforcement is strong, a lender might not have sufficient information about a borrower and thus might reject the initial loan application and cut the initial loan size in order to elicit more information if the degree of judicial enforcement is strong.

Furthermore, we explored the impact of the degree of judicial enforcement on the probability of bankruptcy and found that better judicial enforcement increases the probability of bankruptcy. This finding is consistent with the lax screening effect, whereby better judicial enforcement increases the probability of bankruptcy because improvements in the degree of judicial enforcement reduce the bank's incentive to screen borrowers adequately and worsen the quality of credit allocation.

In sum, our estimation results found that better judicial enforcement facilitates the recovery of loans but that it may be socially harmful because it reduces the amount of credit granted to households and increases their bankruptcy rate. Thus, better judicial enforcement may not necessarily be a good thing. 


\section{Acknowledgments}

We would like to thank David Blau, Lucia Dunn, Shinya Kajitani, Mari Kan, Wataru Kureishi, Howard P. Marvel, Colin R. McKenzie, Masao Ogaki, Tae Okada, Hiroko Okudaira, Kei Sakata, Keiko Tamada, Midori Wakabayashi, Bruce Weinberg, Keiko Yoshida, and all members of Groupe d'Analyse et de Theorie Economique (GATE), Lyon, France, for their useful advice and suggestions. Moreover, we greatly appreciate detailed comments provided by Alberto Zazzaro, which enabled us to significantly improve our paper. In addition, we would like to thank the Institute for Research on Household Economics for providing micro data from the Japanese Panel Survey of Consumers for the 2003-07 period. This paper was prepared while the second author, Shizuka Sekita, was visiting GATE. Any remaining errors are our own. 


\section{References}

Alessandrini, P., Presbitero, A. F., and Zazzaro, A. (2009), 'Banks, Distances and Firms' Financing Constraints,' Review of Finance, 13, 261-307.

Berkowitz, J. and White, M. J. (2004), 'Bankruptcy and Small Firms' Access to Credit,' RAND Journal of Economics, 35, 69-84.

Brown, M., Jappelli, T., and Pagano, M. (2009), 'Information Sharing and Credit: Firm-Level Evidence from Transition Countries,' Journal of Financial Intermediation, $18,151-172$.

Cox, D. and Jappelli, T. (1993), 'The Effect of Borrowing Constraints on Consumer Liabilities,' Journal of Money, Credit and Banking, 25, 197-213.

Djankov, S., La Porta, R., Lopez-de-Silanes, F., and Shleifer, A. (2003), 'Courts,' Quarterly Journal of Economics, 118, 453-517.

Duca, J. V. and Rosenthal, S. S. (1993), 'Borrowing Constraints, Household Debt, and Racial Discrimination in Loan Markets,' Journal of Financial Intermediation, 3, 77-103.

Duygan-Bump, B. and Grant, C. (2009), 'Household Debt Repayment Behaviour: What Role Do Institutions Play?' Economic Policy, 24, 107-140.

Fabbri, D. (2002), 'Legal Institutions, Corporate Governance and Aggregate Activity: Theory and Evidence,' Centre for Studies in Economics and Finance (CSEF), Working Paper No. 72.

Fabbri, D. and Padula, M. (2004), 'Does Poor Judicial Enforcement Make Households Credit-Constrained?' Journal of Banking and Finance, 28, 2369-2397.

Fay, S., Hurst, E., and White, M. J. (2002), 'The Household Bankruptcy Decision,' American Economic Review, 92, 706-718. 
Grant, C. and Padula, Mario (2006), 'Informal Credit Markets, Judicial Costs and Consumer Credit: Evidence from Firm Level Data,' Centre for Studies in Economics and Finance (CSEF) Working Paper, 155.

Gropp, R., Scholz, J. K., and White, M. J. (1997), 'Personal Bankruptcy and Credit Supply and Demand,' Quarterly Journal of Economics, 112, 217-251.

Jappelli, T. (1990), 'Who is Credit Constrained in the U.S. Economy?' Quarterly Journal of Economics, 105, 219-234.

Jappelli, T., Pagano, M., and Bianco, M. (2005), 'Courts and Banks: Effects of Judicial Enforcement on Credit Markets,' Journal of Money, Credit and Banking, 37, 223-244.

Kohara, M. and Horioka, C. Y. (2006), 'Do Borrowing Constraints Matter? An Analysis of Why the Permanent Income Hypothesis Does Not Apply in Japan,' Japan and the World Economy, 18, 358-377.

La Porta, R., Lopez-De-Silanes, F., Shleifer, A., and Vishny, R. W. (1997), 'Legal Determinants of External Finance,' Journal of Finance, 52, 1131-1150.

Magri, S. (2007), 'Italian Households' Debt: The Participation to the Debt Market and the Size of the Loan,' Empirical Economics, 33, 401-426.

Manove, M., Padilla, A. J., and Pagano, M. (2001), 'Collateral versus Project Screening: A Model of Lazy Banks,' RAND Journal of Economics, 32, 726-744.

Zazzaro, A. (2005), 'Should Courts Enforce Credit Contracts Strictly?' Economic Journal, 115, 166-184. 
Figure 1: The Length of Civil Trials (in Months) in District Courts (Upper Graph: 2000; Lower Graph: 2006)

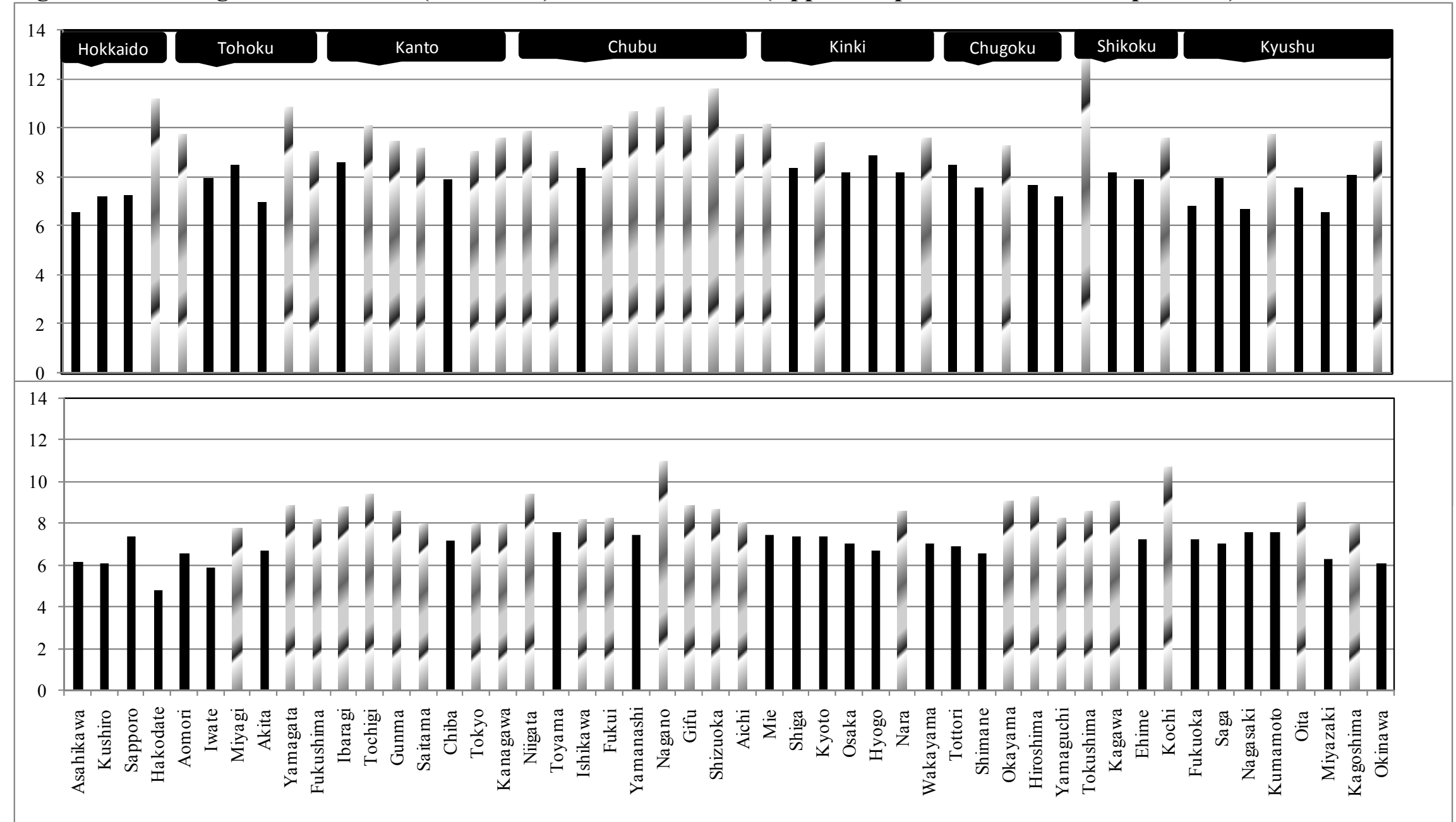

Source: The Public Relations Division of the Supreme Court. Note: The length of trials measures the time elapsed between the date of the initial recording of a trial and that of the court verdict. Trials include all first civil trials in district courts. 
Figure 2: Number of Pending Trials / Number of Incoming Trials in District Courts (Upper Graph: 2000; Lower Graph: 2006)

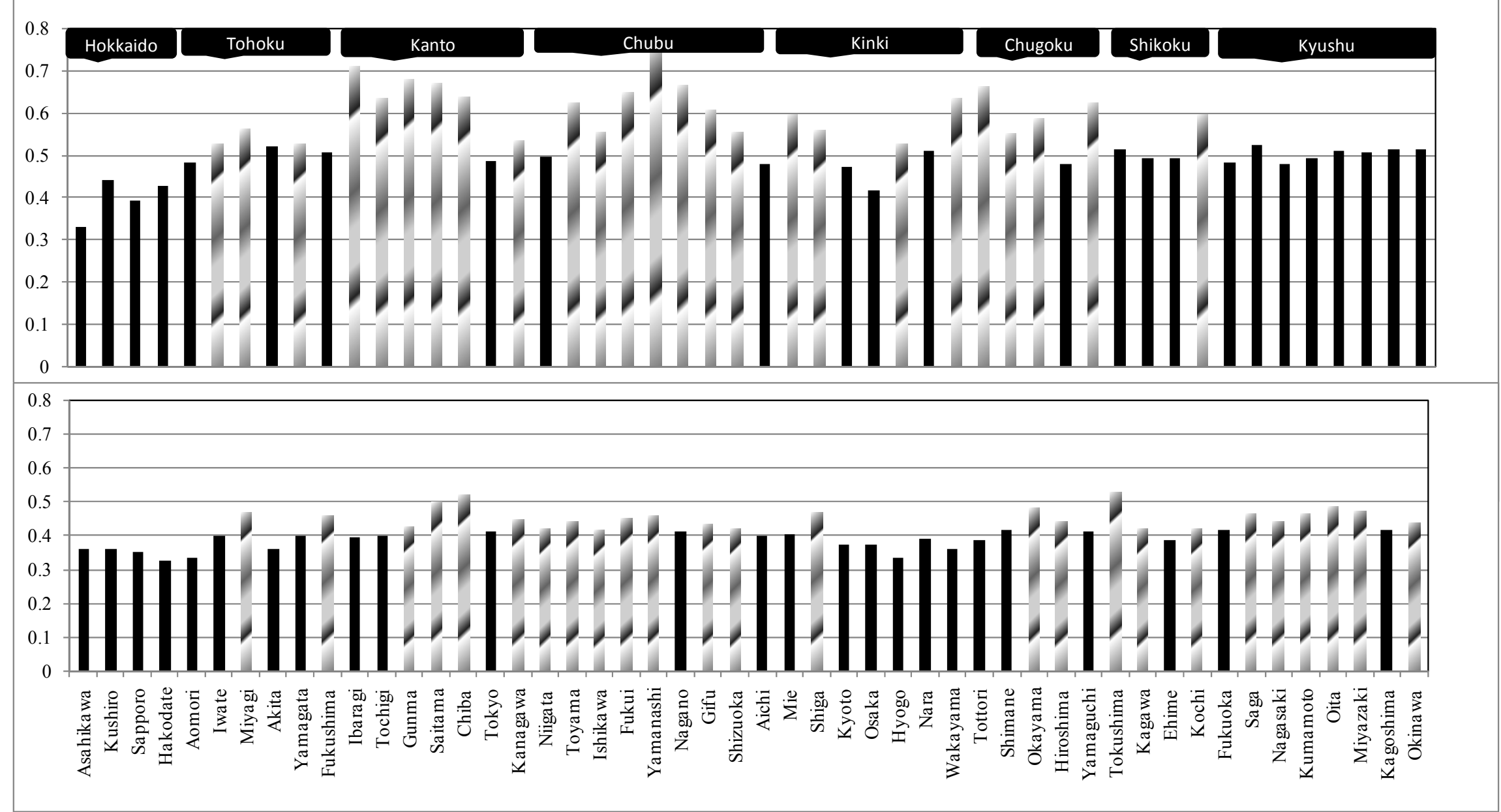

Source: Annual Report of Judicial Statistics. 1. Civil Cases (2000, 2006). General Secretariat, Supreme Court.

Note: Trials include all civil trials in district courts with the exception of work- and family-related cases. 
Table 1: Characteristics of Households that Applied for a Loan

\begin{tabular}{|c|c|c|c|c|c|c|}
\hline & \multicolumn{2}{|c|}{ Full } & \multicolumn{2}{|c|}{ Non-Rationed } & \multicolumn{2}{|c|}{ Rationed } \\
\hline & Mean & S.D. & Mean & S.D. & Mean & S.D. \\
\hline $1^{\text {st }}$ Enforcement Quartilel (dummy variable) & 0.25 & 0.44 & 0.25 & 0.44 & 0.25 & 0.43 \\
\hline $2^{\text {nd }}$ Enforcement Quartilel (dummy variable) & 0.19 & 0.39 & 0.18 & 0.39 & 0.23 & 0.42 \\
\hline $3^{r d}$ Enforcement Quartile1 (dummy variable) & 0.30 & 0.46 & 0.30 & 0.46 & 0.30 & 0.46 \\
\hline $1^{\text {st }}$ Enforcement Quartile2 (dummy variable) & 0.24 & 0.43 & 0.23 & 0.42 & 0.29 & 0.45 \\
\hline $2^{\text {nd }}$ Enforcement Quartile2 (dummy variable) & 0.29 & 0.45 & 0.30 & 0.46 & 0.26 & 0.44 \\
\hline $3^{r d}$ Enforcement Quartile2 (dummy variable) & 0.22 & 0.41 & 0.23 & 0.42 & 0.17 & 0.38 \\
\hline$A G E$ & 37.33 & 8.00 & 37.53 & 7.71 & 36.58 & 9.00 \\
\hline$I N C$ (in tens of thousands of yen) & 26.27 & 15.16 & 27.21 & 14.38 & 22.73 & 17.39 \\
\hline$W E A L T H$ (in tens of thousands of yen) & 1610.16 & 2063.73 & 1812.85 & 2172.03 & 846.98 & 1345.35 \\
\hline HOME (dummy variable) & 0.60 & 0.49 & 0.65 & 0.48 & 0.44 & 0.50 \\
\hline$L O A N$ (in tens of thousands of yen) & 956.40 & 1185.51 & 1006.01 & 1195.18 & 769.62 & 1132.88 \\
\hline SELF-EMPLOYED (dummy variable) & 0.13 & 0.33 & 0.11 & 0.32 & 0.19 & 0.39 \\
\hline UNEMPLOYED (dummy variable) & 0.04 & 0.20 & 0.03 & 0.17 & 0.09 & 0.28 \\
\hline$R E P A Y$ (in ratio form) & 0.35 & 0.42 & 0.32 & 0.38 & 0.43 & 0.57 \\
\hline TENURE (dummy variable) & 0.77 & 0.42 & 0.82 & 0.39 & 0.60 & 0.49 \\
\hline COLLEGE (dummy variable) & 0.23 & 0.42 & 0.25 & 0.43 & 0.14 & 0.35 \\
\hline MARRIED (dummy variable) & 0.77 & 0.42 & 0.77 & 0.42 & 0.75 & 0.43 \\
\hline CHILD & 1.62 & 1.15 & 1.57 & 1.13 & 1.79 & 1.20 \\
\hline METRO (dummy variable) & 0.23 & 0.42 & 0.24 & 0.43 & 0.17 & 0.38 \\
\hline MEDIUM CITY (dummy variable) & 0.65 & 0.48 & 0.64 & 0.48 & 0.71 & 0.45 \\
\hline PREFECTURAL GDP (in billions of yen) & 4.37 & 1.29 & 4.43 & 1.32 & 4.15 & 1.16 \\
\hline$B A D L O A N S$ (in percent) & 5.14 & 1.92 & 5.10 & 1.90 & 5.29 & 1.98 \\
\hline HERFINDAHL (in percent) & 54.58 & 23.82 & 54.02 & 23.92 & 56.70 & 23.36 \\
\hline$D E P T H$ (in ratio form) & 0.68 & 0.38 & 0.69 & 0.39 & 0.65 & 0.34 \\
\hline Number of Observations & 710 & & 561 & & 149 & \\
\hline
\end{tabular}

Note: Data was taken from the Japanese Panel Survey of Consumers for the 2003-07 period. "Full" refers to all households that applied for a loan during the past year. "Non-Rationed" refers to households that applied for a loan but were not rationed during the past year. "Rationed" refers to households that not only applied for a loan but also had their loan applications rejected and/or their loan amount reduced during the past year. 
Table 2: Judicial Enforcement and the Probability of Being Credit Rationed

\begin{tabular}{|c|c|c|c|c|}
\hline \multirow[b]{3}{*}{ Explanatory Variable } & \multicolumn{2}{|c|}{ Pooling Logit } & \multicolumn{2}{|c|}{ Random Effects Logit } \\
\hline & \multicolumn{2}{|c|}{$\begin{array}{l}\text { Marginal Effect } \\
\text { (Standard Error) }\end{array}$} & \multicolumn{2}{|c|}{$\begin{array}{c}\text { Marginal Effect } \\
\text { (Standard Error) }\end{array}$} \\
\hline & $(1)$ & $(2)$ & (3) & (4) \\
\hline \multirow{2}{*}{$1^{\text {st }}$ Enforcement Quartilel } & 0.0373 & & 0.0514 & \\
\hline & $(0.0623)$ & & $(0.1415)$ & \\
\hline \multirow[t]{2}{*}{$2^{\text {nd }}$ Enforcement Quartile1 } & $0.1066 *$ & & 0.1514 & \\
\hline & $(0.0647)$ & & $(0.1383)$ & \\
\hline \multirow{2}{*}{$3^{\text {rd }}$ Enforcement Quartile1 } & 0.0485 & & 0.1081 & \\
\hline & $(0.0471)$ & & $(0.1127)$ & \\
\hline \multirow[t]{2}{*}{$1^{\text {st }}$ Enforcement Quartile2 } & & -0.0178 & & -0.0519 \\
\hline & & $(0.0560)$ & & $(0.1436)$ \\
\hline \multirow[t]{2}{*}{$2^{\text {nd }}$ Enforcement Quartile2 } & & -0.0308 & & -0.0785 \\
\hline & & $(0.0404)$ & & $(0.1066)$ \\
\hline \multirow[t]{2}{*}{$3^{r d}$ Enforcement Quartile2 } & & -0.0375 & & -0.0740 \\
\hline & & $(0.0426)$ & & $(0.1003)$ \\
\hline \multirow[t]{2}{*}{$A G E$} & $-0.0430 * *$ & $-0.0435 * *$ & $-0.0826 *$ & $-0.0816^{*}$ \\
\hline & $(0.0175)$ & $(0.0177)$ & $(0.0451)$ & $(0.0448)$ \\
\hline \multirow[t]{2}{*}{$A G E D$} & $0.0005 * *$ & $0.0005 * *$ & $0.0010 *$ & $0.0010 *$ \\
\hline & $(0.0002)$ & $(0.0002)$ & $(0.0006)$ & $(0.0006)$ \\
\hline \multirow[t]{2}{*}{ LINC } & 0.0027 & 0.0033 & 0.0051 & 0.0054 \\
\hline & $(0.0061)$ & $(0.0064)$ & $(0.0174)$ & $(0.0177)$ \\
\hline \multirow[t]{2}{*}{ LWEALTH } & $-0.0089 * *$ & $-0.0088 * *$ & $-0.0156 *$ & -0.0152 \\
\hline & $(0.0037)$ & $(0.0038)$ & $(0.0094)$ & $(0.0095)$ \\
\hline \multirow[t]{2}{*}{$H O M E$} & 0.0180 & 0.0188 & -0.0135 & -0.0139 \\
\hline & $(0.0507)$ & $(0.0511)$ & $(0.1333)$ & $(0.1337)$ \\
\hline \multirow[t]{2}{*}{$L L O A N$} & $-0.0337 * * *$ & $-0.0331 * * *$ & $-0.0742 * * *$ & $-0.0726 * * *$ \\
\hline & $(0.0050)$ & $(0.0049)$ & $(0.0218)$ & $(0.0224)$ \\
\hline \multirow[t]{2}{*}{$S E L F-E M P L O Y E D$} & 0.0788 & $0.0966 *$ & 0.1505 & 0.1751 \\
\hline & $(0.0541)$ & $(0.0554)$ & $(0.1236)$ & $(0.1183)$ \\
\hline \multirow[t]{2}{*}{ UNEMPLOYED } & 0.0037 & 0.0096 & 0.0730 & 0.0744 \\
\hline & $(0.0832)$ & $(0.0865)$ & $(0.2364)$ & $(0.2360)$ \\
\hline \multirow[t]{2}{*}{$R E P A Y$} & $0.1173 * * *$ & $0.1134 * * *$ & $0.2284 * *$ & $0.2151 * *$ \\
\hline & $(0.0396)$ & $(0.0390)$ & $(0.1085)$ & $(0.1112)$ \\
\hline \multirow[t]{2}{*}{ TENURE } & $-0.1310 * *$ & $-0.1387 * *$ & $-0.2774 * *$ & $-0.2888 * *$ \\
\hline & $(0.0547)$ & $(0.0561)$ & $(0.1158)$ & $(0.1206)$ \\
\hline \multirow[t]{2}{*}{ COLLEGE } & -0.0065 & -0.0107 & -0.0425 & -0.0516 \\
\hline & $(0.0497)$ & $(0.0495)$ & $(0.1168)$ & $(0.1160)$ \\
\hline \multirow[t]{2}{*}{ MARRIED } & $0.0729 *$ & $0.0727 *$ & $0.1915 *$ & $0.1880 *$ \\
\hline & $(0.0397)$ & $(0.0402)$ & $(0.1063)$ & $(0.1088)$ \\
\hline \multirow[t]{2}{*}{ CHILD } & $0.0443 * *$ & $0.0426 * *$ & $0.0895 * *$ & $0.0857 * *$ \\
\hline & $(0.0183)$ & $(0.0184)$ & $(0.0435)$ & $(0.0436)$ \\
\hline \multirow[t]{2}{*}{ METRO } & -0.0289 & -0.0252 & -0.0496 & -0.0436 \\
\hline & $(0.0520)$ & $(0.0551)$ & $(0.1482)$ & $(0.1537)$ \\
\hline
\end{tabular}


Table 2: Judicial Enforcement and the Probability of Being Credit Rationed (Cont'd)

\begin{tabular}{|c|c|c|c|c|}
\hline \multirow[t]{2}{*}{ MEDIUM CITY } & 0.0103 & 0.0082 & 0.0267 & 0.0159 \\
\hline & $(0.0423)$ & $(0.0435)$ & $(0.1106)$ & $(0.1093)$ \\
\hline \multirow[t]{2}{*}{ PREFECTURAL GDP } & $-0.0616 *$ & $-0.0599 *$ & -0.1360 & -0.1209 \\
\hline & $(0.0358)$ & $(0.0340)$ & $(0.0908)$ & $(0.0898)$ \\
\hline \multirow[t]{2}{*}{$B A D L O A N S$} & -0.0054 & -0.0071 & -0.0136 & -0.0162 \\
\hline & $(0.0105)$ & $(0.0101)$ & $(0.0265)$ & $(0.0257)$ \\
\hline \multirow[t]{2}{*}{ HERFINDAHL } & -0.0000 & 0.0000 & -0.0002 & 0.0001 \\
\hline & $(0.0011)$ & $(0.0010)$ & $(0.0023)$ & $(0.0022)$ \\
\hline \multirow[t]{2}{*}{ DEPTH } & 0.1954 & $0.2147 *$ & 0.4116 & 0.4339 \\
\hline & $(0.1279)$ & $(0.1244)$ & $(0.3539)$ & $(0.3457)$ \\
\hline Number of Observations & 710 & 710 & 710 & 710 \\
\hline Wald $\mathrm{Chi}^{2}(33)$ & 132.91 & 122.27 & 85.55 & 87.66 \\
\hline Prob $>\mathrm{Chi}^{2}$ & 0.0000 & 0.0000 & 0.0000 & 0.0000 \\
\hline Log Likelihood & -281.06277 & -282.45244 & -272.80040 & -273.48984 \\
\hline Pseudo R-squared & 0.2295 & 0.2257 & & \\
\hline LR test of rho $=0: \operatorname{chibar}^{2}(01)$ & - & - & 16.52 & 17.93 \\
\hline Prob $>=$ Chibar $^{2}$ & - & - & 0.000 & 0.000 \\
\hline
\end{tabular}

Note: The dependent variable is a dummy variable that equals one if the household's loan application was rejected and/or its loan amount was reduced during the past year and zero otherwise. In addition, we also included seven area dummies and four year dummies, but their marginal effects and standard errors are not shown. Moreover, the marginal effects of the continuous variables were evaluated at their means and those of dummy variables show the change in the dependent variable when the value of the dummy variable changes from zero to one. Furthermore, the standard errors in the pooling logit model were adjusted for clustering on households and those in the random effects logit model were bootstrapped. Finally, ${ }^{*}, *$, and $* * *$ indicate significance at the $10 \%, 5 \%$, and $1 \%$ levels, respectively. 
Table 3: Judicial Enforcement and Loan Size

\begin{tabular}{|c|c|c|c|c|}
\hline \multirow[b]{2}{*}{ Explanatory Variable } & \multicolumn{2}{|c|}{ Pooling Tobit } & \multicolumn{2}{|c|}{ Random Effects Tobit } \\
\hline & \multicolumn{2}{|c|}{ (Standard Error) } & Marginal Effect & (Standard Error) \\
\hline \multirow[t]{2}{*}{$1^{\text {st }}$ Enforcement Quartilel } & $-1.6918 * * *$ & & $-1.5215 * * *$ & \\
\hline & $(0.6617)$ & & $(0.5158)$ & \\
\hline \multirow[t]{2}{*}{$2^{\text {nd }}$ Enforcement Quartile1 } & $-1.7145 * * *$ & & $-1.4181 * * *$ & \\
\hline & $(0.5832)$ & & $(0.4798)$ & \\
\hline \multirow[t]{2}{*}{$3^{r d}$ Enforcement Quartilel } & $-0.9435 * *$ & & $-0.8137 * *$ & \\
\hline & $(0.4146)$ & & $(0.3559)$ & \\
\hline \multirow[t]{2}{*}{$1^{\text {st }}$ Enforcement Quartile2 } & & 0.2255 & & 0.1571 \\
\hline & & $(0.7102)$ & & $(0.6544)$ \\
\hline \multirow[t]{2}{*}{$2^{\text {nd }}$ Enforcement Quartile2 } & & 0.2340 & & 0.2044 \\
\hline & & $(0.5237)$ & & $(0.5327)$ \\
\hline \multirow[t]{2}{*}{$3^{r d}$ Enforcement Quartile2 } & & 0.6300 & & 0.4304 \\
\hline & & $(0.4669)$ & & $(0.4411)$ \\
\hline \multirow[t]{2}{*}{$A G E$} & 0.2169 & 0.2039 & 0.1905 & 0.1741 \\
\hline & $(0.2128)$ & $(0.2122)$ & $(0.1795)$ & $(0.1782)$ \\
\hline \multirow[t]{2}{*}{$A G E D$} & -0.0024 & -0.0022 & -0.0021 & -0.0019 \\
\hline & $(0.0026)$ & $(0.0026)$ & $(0.0022)$ & $(0.0022)$ \\
\hline \multirow[t]{2}{*}{ LINC } & 0.0361 & 0.0266 & 0.0398 & 0.0323 \\
\hline & $(0.0820)$ & $(0.0821)$ & $(0.0726)$ & $(0.0732)$ \\
\hline \multirow[t]{2}{*}{ LWEALTH } & $0.1381 * * *$ & $0.1354 * * *$ & $0.1026 * * *$ & $0.0995 * * *$ \\
\hline & $(0.0394)$ & $(0.0397)$ & $(0.0364)$ & $(0.0361)$ \\
\hline \multirow[t]{2}{*}{ HOME } & $-1.6883 * * *$ & $-1.6963 * * *$ & $-1.3240 * * *$ & $-1.3273 * * *$ \\
\hline & $(0.4209)$ & $(0.4296)$ & $(0.4367)$ & $(0.4290)$ \\
\hline \multirow[t]{2}{*}{$L L O A N$} & $0.9339 * * *$ & $0.9297 * * *$ & $0.8399 * * *$ & $0.8379 * * *$ \\
\hline & $(0.0693)$ & $(0.0699)$ & $(0.0451)$ & $(0.0463)$ \\
\hline \multirow[t]{2}{*}{$S E L F-E M P L O Y E D$} & 0.5594 & 0.4693 & 0.4663 & 0.4020 \\
\hline & $(0.5836)$ & $(0.5861)$ & $(0.5616)$ & $(0.5468)$ \\
\hline \multirow[t]{2}{*}{ UNEMPLOYED } & -0.1760 & -0.2481 & -0.2498 & -0.2945 \\
\hline & $(1.4252)$ & $(1.4455)$ & $(1.2855)$ & $(1.2659)$ \\
\hline \multirow[t]{2}{*}{$R E P A Y$} & -0.1075 & -0.1267 & 0.0790 & 0.0502 \\
\hline & $(0.2663)$ & $(0.2718)$ & $(0.3213)$ & $(0.3362)$ \\
\hline \multirow[t]{2}{*}{ TENURE } & 0.7798 & $0.8574 *$ & 0.6576 & $0.7454 *$ \\
\hline & $(0.5270)$ & $(0.5342)$ & $(0.4487)$ & $(0.4509)$ \\
\hline \multirow[t]{2}{*}{ COLLEGE } & 0.3982 & 0.4334 & 0.4371 & 0.4611 \\
\hline & $(0.3555)$ & $(0.3514)$ & $(0.3532)$ & $(0.3656)$ \\
\hline \multirow[t]{2}{*}{ MARRIED } & $-0.9992 *$ & $-1.0121 *$ & $-0.8612 *$ & $-0.8681 *$ \\
\hline & $(0.5393)$ & $(0.5523)$ & $(0.4689$ & $(0.4839)$ \\
\hline \multirow[t]{2}{*}{ CHILD } & $-0.4378 * *$ & $-0.4257 * *$ & $-0.4080 * *$ & $-0.4074 * *$ \\
\hline & $(0.2234)$ & $(0.2223)$ & $(0.1811)$ & $(0.1815)$ \\
\hline METRO & 0.4304 & 0.3543 & 0.3787 & 0.3095 \\
\hline & $(0.6164)$ & $(0.6354)$ & $(0.5592)$ & $(0.5592)$ \\
\hline
\end{tabular}


Table 3: Judicial Enforcement and Loan Size (Cont'd)

\begin{tabular}{|c|c|c|c|c|}
\hline \multirow[t]{2}{*}{ MEDIUM CITY } & 0.2369 & 0.2411 & 0.2153 & 0.2257 \\
\hline & $(0.5154)$ & $(0.5252)$ & $(0.4249)$ & $(0.4200)$ \\
\hline \multirow[t]{2}{*}{ PREFECTURAL GDP } & -0.1740 & 0.0145 & -0.2106 & -0.0332 \\
\hline & $(0.3917)$ & $(0.3574)$ & $(0.4045)$ & $(0.3341)$ \\
\hline \multirow[t]{2}{*}{$B A D L O A N S$} & 0.0218 & 0.0741 & 0.0126 & 0.0586 \\
\hline & $(0.1091)$ & $(0.1054)$ & $(0.1088)$ & $(0.1077)$ \\
\hline \multirow[t]{2}{*}{ HERFINDAHL } & -0.0029 & 0.0007 & -0.0041 & -0.0004 \\
\hline & $(0.0120)$ & $(0.0111)$ & $(0.0119)$ & $(0.0107)$ \\
\hline \multirow[t]{2}{*}{ DEPTH } & 0.7346 & -0.1304 & 0.7855 & 0.0267 \\
\hline & $(1.3432)$ & $(1.2800)$ & $(1.3922)$ & $(1.2463)$ \\
\hline Number of Observations & 710 & 710 & 710 & 710 \\
\hline Wald $\mathrm{Chi}^{2}(33)$ & 337.08 & 326.05 & 343.99 & 359.68 \\
\hline Prob $>\mathrm{Chi}^{2}$ & 0.0000 & 0.0000 & 0.0000 & 0.0000 \\
\hline Log Likelihood & -1868.818 & -1872.38 & -1860.7007 & -1864.3334 \\
\hline LR test of sigma_u $=0: \operatorname{chibar}^{2}(01)$ & - & - & 16.23 & 16.09 \\
\hline Prob $>=$ Chibar $^{2}$ & - & - & 0.000 & 0.000 \\
\hline
\end{tabular}

Note: The dependent variable is the logarithm of the loan amount granted during the past year. We also controlled for seven area dummies and four year dummies, but their marginal effects and standard errors are not shown. Moreover, marginal effects of continuous variables were evaluated at means and those of dummy variables are discrete changes as dummy variables change from zero to one. In addition, standard errors in the pooling Tobit model were adjusted for clustering on households and those in the random effects Tobit model were bootstrapped. Finally, *,**, and *** indicate significance at the $10 \%, 5 \%$, and $1 \%$ levels, respectively. 
Table 4: Judicial Enforcement and the Probability of Bankruptcy

\begin{tabular}{|c|c|c|}
\hline \multirow[b]{2}{*}{ Explanatory Variable } & \multicolumn{2}{|c|}{ Pooling Probit } \\
\hline & $\begin{array}{l}\text { Marginal Effect } \\
\text { (Standard Error) }\end{array}$ & $\begin{array}{l}\text { Marginal Effect } \\
\text { (Standard Error) }\end{array}$ \\
\hline \multirow[t]{2}{*}{$1^{s t}$ Enforcement Quartilel } & $0.0016^{* *}$ & \\
\hline & $(0.0015)$ & \\
\hline \multirow{2}{*}{$2^{\text {nd }}$ Enforcement Quartile1 } & $0.0021 * * *$ & \\
\hline & $(0.0014)$ & \\
\hline \multirow[t]{2}{*}{$3^{r d}$ Enforcement Quartile1 } & -0.0002 & \\
\hline & $(0.0002)$ & \\
\hline \multirow[t]{2}{*}{$1^{s t}$ Enforcement Quartile2 } & & $0.0012 *$ \\
\hline & & $(0.0011)$ \\
\hline \multirow[t]{2}{*}{$2^{\text {nd }}$ Enforcement Quartile2 } & & 0.0007 \\
\hline & & $(0.0007)$ \\
\hline \multirow[t]{2}{*}{$3^{r d}$ Enforcement Quartile2 } & & -0.0002 \\
\hline & & $(0.0003)$ \\
\hline \multirow[t]{2}{*}{ DIVORCE } & $0.0197 * * *$ & $0.0224 * * *$ \\
\hline & $(0.0151)$ & $(0.0156)$ \\
\hline \multirow[t]{2}{*}{ LOST JOB } & $0.0101 * * *$ & $0.0106 * * *$ \\
\hline & $(0.0069)$ & $(0.0070)$ \\
\hline \multirow[t]{2}{*}{ SICK } & $0.0011 * * *$ & $0.0015 * * *$ \\
\hline & $(0.0008)$ & $(0.0010)$ \\
\hline \multirow[t]{2}{*}{$A G E$} & -0.0000 & -0.0001 \\
\hline & $(0.0001)$ & $(0.0001)$ \\
\hline \multirow[t]{2}{*}{$A G E D$} & 0.0000 & 0.0000 \\
\hline & $(0.0000)$ & $(0.0000)$ \\
\hline \multirow[t]{2}{*}{$L I N C$} & -0.0000 & -0.0000 \\
\hline & $(0.0000)$ & $(0.0000)$ \\
\hline \multirow[t]{2}{*}{ LWEALTH } & $-0.0001 * * *$ & $-0.0001 * * *$ \\
\hline & $(0.0000)$ & $(0.0000)$ \\
\hline \multirow[t]{2}{*}{ HOME } & -0.0003 & -0.0003 \\
\hline & $(0.0004)$ & $(0.0005)$ \\
\hline \multirow[t]{2}{*}{$L L O A N$} & 0.0000 & 0.0000 \\
\hline & $(0.0000)$ & $(0.0000)$ \\
\hline \multirow[t]{2}{*}{$S E L F-E M P L O Y E D$} & $0.0015 * * *$ & $0.0019 * * *$ \\
\hline & $(0.0013)$ & $(0.0016)$ \\
\hline \multirow[t]{2}{*}{$R E P A Y$} & $0.0001 *$ & $0.0002 *$ \\
\hline & $(0.0001)$ & $(0.0001)$ \\
\hline
\end{tabular}


Table 4: Judicial Enforcement and the Probability of Bankruptcy (Cont'd)

\begin{tabular}{|c|c|c|}
\hline TENURE & $\begin{array}{l}-0.0033 * * * \\
(0.0019)\end{array}$ & $\begin{array}{l}-0.0043 * * * \\
(0.0024)\end{array}$ \\
\hline \multirow[t]{2}{*}{ COLLEGE } & -0.0001 & -0.0001 \\
\hline & $(0.0002)$ & $(0.0003)$ \\
\hline \multirow[t]{2}{*}{ MARRIED } & $0.0007 * * *$ & $0.0009 * * *$ \\
\hline & $(0.0004)$ & $(0.0005)$ \\
\hline \multirow[t]{2}{*}{$C H I L D$} & -0.0000 & 0.0000 \\
\hline & $(0.0001)$ & $(0.0001)$ \\
\hline \multirow[t]{2}{*}{ METRO } & 0.0001 & 0.0001 \\
\hline & $(0.0003)$ & $(0.0004)$ \\
\hline \multirow[t]{2}{*}{ MEDIUM CITY } & -0.0001 & -0.0001 \\
\hline & $(0.0003)$ & $(0.0004)$ \\
\hline \multirow[t]{2}{*}{ PREFECTURAL GDP } & 0.0002 & -0.0000 \\
\hline & $(0.0002)$ & $(0.0003)$ \\
\hline \multirow[t]{2}{*}{ BAD LOANS } & $0.0001 *$ & 0.0001 \\
\hline & $(0.0001)$ & $(0.0001)$ \\
\hline \multirow[t]{2}{*}{ HERFINDAHL } & $-0.0000 * * *$ & $-0.0000 * * *$ \\
\hline & $(0.0000)$ & $(0.0000)$ \\
\hline \multirow[t]{2}{*}{ DEPTH } & -0.0011 & -0.0006 \\
\hline & $(0.0009)$ & $(0.0011)$ \\
\hline Number of Observations & 6222 & 6222 \\
\hline Wald $\mathrm{Chi}^{2}(35)$ & 211.57 & 200.76 \\
\hline Prob $>\mathrm{Chi}^{2}$ & 0.0000 & 0.0000 \\
\hline Log Pseudolikelihood & -142.60904 & -144.66652 \\
\hline Pseudo R-squared & 0.3404 & 0.3309 \\
\hline
\end{tabular}

Note: The dependent variable is a dummy variable that equals one if the household experienced personal bankruptcy and/or the bankruptcy of its own company during the past year and/or faced difficulties with loan repayments during the past year and zero otherwise. We also controlled for seven area dummies and four year dummies, but their marginal effects and standard errors are not shown. In addition, the marginal effects of the continuous variables were evaluated at their means and those of dummy variables show the change in the dependent variable when the value of the dummy variable changes from zero to one. Moreover, standard errors were adjusted for clustering on households. Finally, *,**, and $* * *$ indicate significance at the $10 \%, 5 \%$, and $1 \%$ levels, respectively. 